\title{
IMPACT OF POLLUTION ON PRODUCTIVITY AND FISHERIES OF FISHERIES OF LAKE MARIUT, EGYPT
}

\section{Magdy T. Khalil}

Zoology Department, Faculty of Science, Ain Shams university, Cairo, Egypt.

(Received Oct. 19, 1997)

Keywords : industrial pollution, sewage, drainage wastes, primary production, fish yield, heavy metals.

\section{ABSTRACT}

$\mathbf{V}$ ater quality characteristics of Lake Mariut (Egypt) were investigated during the period from April 1996 to March 1997. A comparison of nutrient salts and oxygen concentrations during late 1950's with those of the present study, indicated a pattern of increasing eutrophication and organic pollution and dominance of the sewage, industrial and agricultural wastewaters on the ecology of the lake. In the polluted main basin, the water showed much higher concentration: of some heavy metals such as iron, copper and zinc. Accumulation levels of heavy metals in fish muscles are within the legal limits of WHO standards.

In response to the heavy pollution, the primary production and fertility of the main basin of the lake were reduced to about $1 / 3$ of that recorded in 1961 . The average annual fish production declined from $1850 \mathrm{~kg} \mathrm{ha}^{-1}$ in 1970 's to only 461 $\mathrm{kg} \mathrm{ha}^{-1}$ in 1996, and more declining is expected in the near future, unless a management programme is applied to conserve this vital ecosystem. 


\section{INTRODUCTION}

The Egyptian northern Nile-Delta lakes, adjacent to the Mediterranean Sea, are the principal depository for Nile drainage and wastes prior to its outflow in the Sea. These lakes receive the agricultural drainage water and major inputs of municipal and industrial wastes from cities as Cairo, Alexandria and others, in addition to several towns and villages. The National Environmental Action Plan of Egypt (1992) has identified the north-westem Lake "Mariut" as the most polluted aquatic ecosystem in Egypt. The lake receives wastes from two major drains, primary treated sewage from Alexandria city, as well as primary treated industrial wastes from about 40 industrial plants. The outflow discharge from the lake is pumped through "Max" pumping station to the Mediterranean Sea with a total amount of about 2.4 billion $\mathrm{m}^{3}$ year $^{-1}$ with an average salinity of $5,600 \mathrm{ppm}$ (RMP, 1993).

Pollution of the lake has resulted in a considerable decrease of some fish species, disappearance of some valuable ones and reduction of wildlife populations. These deteriorating effects on Lake Mariut have drawn public concern and attention to environmental issues. Therefore, the objective of this study it to investigate the pollutant levels in the lake water and fish muscles as well as to assess the impact of industrial and domestic effluents on productivity and fisheries of the lake.

\section{AREA OF STUDY}

Lake Mariut is the smallest brackish water ecosystem along the Mediterranean coast, situated in the northwestern corner of the Nile Delta, at latitude $31^{\circ} 10^{\prime} \mathrm{N}$ and longitude $29^{\circ} 55^{\prime} \mathrm{E}$ (Fig. 1). It has no connection with neither the Mediterranean Sea nor the River Nile, but there are pumps which discharge water from the lake, at the northern end of Elamoum drain into the sea and the water level in the lake is kept at about $3.8 \mathrm{~m}$ below sea level (El Sharkawy, 1991). 
At the end of the nineteenth century, Lake Mariut occupied an area of about 26,000 hectares (Meininger \& Atta, 1994) but since then the lake has been subjected to various changes due to land reclamation projects, which led to a considerable shrinkage of its total area to about 6,070 hectares, with an average depth of about $1.2 \mathrm{~m}$. Geographically, the lake is divided into four separated sections by Cairo- Alexandria desert road and Elamoum drain (Fig. 1). They are :

1- The northern-west basin (1214 hectares), which receives its water from Elamoum drain.

2- The southern-west basin (2023 hectares), which also receives its water from Elamoum drain and Noubaria canal and is densely covered with Phragmites and Typha spp. plants.

3- The fish farm (405 hectares), which receives its water from the drainage waters of Elamoum and Qallaa drains.

4- The main proper basin ( 2428 hectares), which has been subjected to a serious disturbance in its biological balance, owing to draining of large amounts of municipal and industrial wastewaters from three sources :

a- The Western Collective Treatment Station which discharges the primary treated wastewaters of El-Kabbari, industrial and Gheit El-Ennab drains, at the north west side of the basin.

b- The Eastern Treatment Station which discharges the primary treated wastewater of the Qallaa drain, at the eastern side of the basin.

c- Noubaria Canal which discharges wastewaters at the western side of the basin.

\section{MATERIAL AND METHODS}

This study has been conducted in the main basin of Lake Mariut; the most polluted region and the fish farm basin; the relatively stable and clean portion of 
the lake. Water samples were collected during the period from April, 1996 to March, 1997, at approximately seasonal intervals, at five stations; four in the main basin and one in the fish farm (Fig. 1). Station \# 1 is located at the northern portion of the main basin, in between the mouths of the old industrial wastes drain and Qallaa drain. Station \# 2 is located in front of the old Gheit El-Ennab drain mouth; while station \# 3 is affected by the old El-Kabbari drain. Station \# 4 is situated at the south-west region of the main basin, away from the effect of the wastes effluents. Station \# 5 is located in the middle of the fish farm.

Water samples were taken from the upper $0.5 \mathrm{~m}$ of the water column by plastic water sampler and were analyzed to determine the concentrations of some chemical and biological parameters. These parameters include field measurements of dissolved oxygen (DO), $\mathrm{pH}$ values and electric conductivity $(E C)$, in addition to laboratory measurements of chlorides, phosphate, nitrate, nitrite, ammonia, sulphate, hydrogen sulphide, biological oxygen demand (BOD), chemical oxygen demand (COD), total coliform bacteria and the heavy metals; iron $(\mathrm{Fe})$, nickel $(\mathrm{Ni})$, zinc $(\mathrm{Zn})$, copper $(\mathrm{Cu})$, lead $(\mathrm{Pb})$, chromium $(\mathrm{Cr})$ and mercury $(\mathrm{Hg})$. Laboratory analysis of water followed the Standard Methods for Examination of Water and Wastewater (1992). Analysis of heavy metals in fish edible muscles and liver of Oreochromis niloticus $(L)$ were carried out according to Chernoff (1975). Metal concentrations were determined using Pye Unicam Sp 191 atomic absorption spectrophotometer.

Primary production experiments were performed at the same stations, using the in situ light-dark bottles method (Strickland, 1960), where duplicate sets of light and dark bottles were filled and suspended at the surface, $0.5 \mathrm{~m}$ and $0.8 \mathrm{~m}$.

\section{RESULTS AND DISCUSSION}

The chemical and bacteriological analyses of main basin water of Lake Mariut indicated that it has been greatly affected by the input of Alexandria sewage and industrial wastewaters (Tables $1 \& 2$ ). The northem sector of the 
main basin (stations \# 1, \# 2 and \# 3) was the most affected area by these pollutants, where the mean dissolved oxygen concentrations were very low and reached to about $0.5,0.3$ and $1.8 \mathrm{mg}^{-1}$, respectively. This reduction in dissolved oxygen at these sites was primarily due to the discharge of the primary treated industrial and municipal wastewaters through the western treatment station, and increasing of ammonia and sulplides (Table 1), which may cause the mineralization of organic matter during eutrophication and induced an enormous oxygen depletion. After an aerobic phase, the microbially-mediated anaerobic decay of plant and animal material was usually malodorous due to production of ammonia and sulphides. These results are in agreement with those obtained by Higgins $\dot{\&}$ Bruns (1975) and Lorenzen (1978).

On the other hand, organic loads have been increased tremendously in this northern sector, therefore the mean biochemical oxygen demand (BOD) reached to about $149.5 \mathrm{mg} \mathrm{O}_{2} \mathrm{l}^{-1}$, while the mean COD amounted to $821.6 \mathrm{mg} \mathrm{O} 2 \mathrm{I}^{-1}$, which indicates a high industrial effect in this region. Total coliform bacteria concentrations in these stations (\#1,2 and 3) were in the range of $3.8 \times 10^{6}, 2.5$ $\times 10^{6}$ and $0.9 \times 10^{6} \mathrm{MPN}^{-1}$, respectively.

At the southem sector of the main basin (station \# 4), the water quality profile indicated a noticeable recovery and a decrease of the pollutants effect which may be attributed to absorption of pollutants by the dense macrophytes; Phragmites and Typha spp. Khalil and Awady (1990) reported that in the middle and western regions of the lake - which are rich in submerged macrophytes - the water quality profile indicated a remarkable recovery and a decrease of the pollutants effect. The oxygen level increased to $6.3 \mathrm{mgl}^{-1}$, the COD and BOD decreased to 170 and $45 \mathrm{mg} \mathrm{l}^{-1}$, respectively, and the number of coliform bacteria was decreased to only $4700 \mathrm{MPN}^{-1}$. Moreover, the concentrations of ammonia and sulphides decreased sharply (Table 1), which indicated that the wastewaters of the western treatment station were mixed up rapidly with the lake water, due to-primarily-the northern south currents (El-Sharkawy, 1978). At the 
fish farm basin (station \# 5), the water quality profile indicated that concentration values of most parameters, even the heavy metals, were well within the established safety range for unrestricted use in fish culture, compared to standards set by FAO (WHO, 1989).

In the main basin, the water showed much higher concentrations of some heavy metals (Table 3), such as iron, copper and zinc. This reflects the discharge of the industrial and sewage wastes into this sector. Saad et al. (1982) have claimed that Tilapia spp. fish in the lake have markedly enhanced concentrations of both heavy metals and organochlorine pesticides. This can be explained if we know that during the present study, high concentrations of heavy metals were found in the liver of tilapias (Table 4), which were not complying with the WHO guidelines. But generally, it is found that the accumulation levels of heavy metals in the fish muscles were within the legal limits of different countries and WHO standards (Nauen, 1983; WHO, 1989).

On the other hand, a comparison of nutrient salts and oxygen concentrations during late 1950's with those of the present study at the same sites (Table 2), indicated a pattern of increasing eutrophication and organic pollution, and dominance of the sewage and agricultural drainage water on the ecology of Lake Mariut. During 1996/97 the total phosphate levels were approximately ten times those of the 1950 's. The mean nitrate value in 1950 's $\left(0.028 \mathrm{mgl}^{-1}\right)$ has been increased to $0.445 \mathrm{mg} \mathrm{I}^{-1}$ in the $1996 / 97$ period. These increases in nutrient saits in Lake Mariut were paralleled by their increases in Lake Manzala, Egypt (Khalil \& Salib, 1986; Khalil \& El-Awamri, 1988), which receives a huge amount of drainage water besides the sewage of Cairo city. Moreover, the annual mean chlorosity levels in Lake Mariut decreased by $66 \%$ since late 1950's. It was about $3670 \mathrm{mg}^{-1}$ during 1957/58 (Wahby, 1961), then $1367 \mathrm{mg} \mathrm{l}^{-1}$ during 1975776 (El-Sharkawy, 1978), $1280 \mathrm{mg} \mathrm{l}^{-1}$ in 1988 (Khalil \& Awady, 1990) and finally $1250 \mathrm{mgl}^{-1}$ during 1996/97 (Table 2). This decrease in salinity pattern over the past 50 years is generally attributed to the continuous increase in the input of 
agricultural drainage water.

In response to the increase of nutrient loading, organic matter, fresh water inputs and the decrease of salinity levels, the productivity and aquatic community have been changed; leading to a less diverse but a high productive ecosystem; tilapia-based fishery. The fish yield has been increased from $167 \mathrm{~kg} \mathrm{ha}^{-1}$ in 1921-26 (Fouad, 1926) to about $992 \mathrm{~kg} \mathrm{ha}^{-1}$ in 1961-65 period then to $1950 \mathrm{~kg}$ $\mathrm{ha}^{-1}$ in 1975-80 (Bishai et al., 1994).

This increase was primarily due to the elevation of nutrient salts levels and consequently primary productivity and plankton; the major diet of tilapia (Bishai \& Khalil, 1990). Since the beginning of 1980's the fish production in Lake Mariut began to decrease sharply due to the enormous increase of industrial wastes and sewage of Alexandria discharged into the lake. During the 1983-88 period the fish yield decreased to about $1120 \mathrm{~kg} \mathrm{ha}^{-1}$, then to only $461 \mathrm{~kg} \mathrm{~h}^{-1}$ in $1990-96$ period (GAFRD, 1997). Table (5) shows the total fish production of Lake Mariut during five periods; from 1921 to 1996.

On the other hand, most of the brackish and less tolerant high-valued fish, such as Mugil cephalus (L.), Labeo niloticus (F.), Bagrus bajad (F.), Lates niloticus ( $L$.) and Barbus bynni $(F$.) , have been decreased or completely disappeared from the lake (GAFRD, 1997). However, Tilapia has been flourished enormously and it represented about $92 \%$ of the total yeild in 1980's. Also, Clarias gariepinus (Buch.) production has been increased from 80 tons in early 1960 's to 300 tons in early 1980's and now it constitutes about $24 \%$ ( 900 tons) of the annual total yield (GAFRD, 1997). The predominance of Tilapia and increase of Clarias gariepinus production in Lake Mariut is due to their high tolerance to marginal environmental conditions, in terms of oxygen concentrations, high nutrient loading and variation in salinity (Balarin, 1979; Khalil \& Awady, 1990). Moreover, because of the herbivorous feeding habit of Tilapia spp., they were able to respond quickly and directly to the flourishing of phytoplankton that 
resulted from nutrient enrichment, especially in the fish farm basin. It is noticed that most of the diversed yield of the lake comes from the fish farm and the western sectors. But, most of fish in the main basin, especially at the northern portion, are very small in size and very low in abundance. This is, definitely, due to the stress of the unfavourable conditions on the fish in this sector which decreased its growth rate.

Other arganisms were also affected by this pollution specially algal flora; the primary producers of the ecosystem. Samaan \& Abdalla (1981) have indicated that the efficiency of periphyton growth and production in the polluted main basin was reduced to about $1 / 4$ of the normal growth rate found in the fish farm, besides the community composition was restricted to few forms which were more tolerant to pollution. Also, Abdalla et al. (1991) reported a decrease of the species diversity of phytoplankton community and domination of tolerant species in the polluted main basin. The gross primary production measurements during the present study, indicated highest values in the fish farm $\left(8.3 \mathrm{~g} \mathrm{C} \mathrm{m}^{-2} \mathrm{~d}^{-1}\right)$ and lowest values in the areas receiving industrial and municipal wastes in the main basin (Table 6). The mean value of production in the polluted main basin was about $1.88 \mathrm{~g} \mathrm{C} \mathrm{m}^{-2} \mathrm{~d}^{-1}$. In 1961, when Lake Mariut was less polluted, Samaan (1966) found that the lake was rich in nutrients and has been ranked as one of the most productive lakes in the world. Its biological productivity was more than 3.5 times that of the other Egyptian northern lakes, and its average gross primary production reached to about $6.84 \mathrm{~g} \mathrm{C} \mathrm{m}^{-2} \mathrm{~d}^{-1}$. Comparing this value with that of the present study in the main basin $(1.88 \mathrm{~g} \mathrm{C}$ $\mathrm{m}^{-2} \mathrm{~d}^{-1}$ ), indicates that fertility of the lake proper has been reduced to about $1 / 3$ of that found in 1961, as a result of pollution, and more declining is expected in the near future, unless a management programme is proposed and applied to conserve the environmental conditions of this vital ecosystem, especially it is considered as one of the most enriched sources of fish production in Egypt. 


\section{REFERENCES}

Abdalla, R.R., A.A. Samaan \& M.G. Ghobrial, (1991): Eutrophication in Lake Mariut. Bull. Inst. Oceanogr. \& Fish. ARE 17(1) : 157-166.

Aleem, A.A. \& A.A. Samaan, (1969): Productivity of Lake Mariut, Egypt. Part 2. Primary production. Int. Revue ges. Hydrobiol; 54 (4) : 491-527.

Balarin, J.D. (1979): Tilapia, a Guide to their Biology and Culture in Africa. University of Stirling, UK.

Bishai, H.M. \& M.T. Khalil, (1990): Estimation of fish production and potential yield in Lake Manzala, Egypt. Arch. Hydrobiol. 119 (3) : 331-337.

Bishai, H.M., S.A. Abdel-Malek \& M.T. Khalil, (1994): Biological Diversity of Egypt, Aquatic Habitat Diversity, 5- Lake Mariut, UNEP and EEAA, GF/6105-92-02-2205, Egypt.

Chernoff, B. (1975): A method for wet digestion of fish tissue for heavy metal analyses. Transactions of the American Fisheries Society. 104 : 803-804.

El-Sharkawy, F.M. (1978): Studies on the pollution of Lake Mariut. Final report of a project. Env. Hyg. Dept., High Inst. Pub. Health, Alexandria University.

El-Sharkawy, F.M. (1991): Management of Lake Mariut Pollution. Proceeding of International Symposium on Environmental Protection, Egypt. 204-218.

Fouad, A.B. (1926): Report of fisheries of Egypt for the year 1925. Ministry of Finance, Egypt. Coast Guards and Fisheries Service Government Press, Cairo.

GAFRD, (1997): General Authority of Fish Resources and Development. Fish Production Report for 1996 year, Agriculture Ministry Press, Cairo.

Higgins, I.J. \& R.G. Bruns, (1975): The Chemistry and Microbiology of 
Pollution. Academic press, London, New York, 248 pp.

Khalil, M.T. \& M.H.M. Awady, (1990): Effect of wastewater on aquatic community of Lake Mariut, Egypt. Scientific Bull., Fac. Eng., Ain-Shams Univ. 25(1) : 298-312.

Khalil, M.T. \& A.A. El-Awamri, (1988): Plankton organisms as bio-indicators for organic pollution at the southem area of Lake Manzala, Egypt. The First National Conference of Environmental Studies and Research, Cairo, Egypt $2: 526-537$.

Khalil, M.T. \& E.A. Salib, (1986): Effect of some water quality parameters on fish composition and productivity in Lake Manzala, Egypt. Proc. Zool. Soc. A.R. Egypt $12: 101-109$.

Lorenzen, M. (1978): Phosphorus models and eutrophication. In : R. Mitchell (Ed.), Water Pollution Microbiology $2: 31-50$.

Meininger, P.L. \& G.A.M. Atta, (1994): Ornithological Studies in Egyptian Wetlands 1989/90. FORE. report Nr. 94-01, WTWO-Report Nr. 40, The Netherlands.

National Environmental Action Plan of Egypt. (1992): Working Paper on Water Resources, Delta Hydraulics, Egypt.

Nauen, C.E. (1983): Compilation of legal limits for hazardous substances in fish and fishery products. FAO Fisheries, Circular No. 764. Rome, Italy. 102 PP.

Reuse Monitoring Programme, (RMP). (1993). Yearbook $1992 / 93$ of Drainage Water in the Nile Delta, Discharges, Salinites and Chemical Composition. Reuse report 38, Drainage Research Institute, Cairo, Egypt. 148 PP.

Saad, M.A.H., M.M. Abu Elamatem, A.H. El-Sebae, \& I.F. Sharaf, (1982). Occurrence and distribution of chemical pollutants in Lake Mariut, Egypt. 1. Residues of Organochlorine pesticides. Water, Air and Soil Pollution 17 : 245-253. 
Samaan, A.A. (1966): Primary production in Lake Mariut. Ph. D. Thesis, Fac. Sci., Alex. Univ., UAR, 365 PP.

Samaan, M.A. \& R.R. Abdalla, 1981. Effect of pollution on the development of periphyton in Lake Mariut, Egypt. Bull. Inst. Oceanogr. \& Fish., ARE. 7 (3) : 527 - 537.

Standard Methods for the Examination of Water and Wastewater. (1992): 18th Edition, APHA, New York.

Strickland, J.D.H. (1960): Measuring of production of marine phytoplankton. Bull. Fish. Res. Bd. Canada 122, 172 PP.

Wahby, S.D. (1961): Chemistry of Lake Mariut. Alex. Inst. Hydrob., Notes and Memoires No. 65, 23 pp.

WHO (1989). Health guidelines for the use of wastewater in agriculture and aquaculture. WHO Technical Report Series, No. 778, 74 pp. World Health Organization, Geneva. 


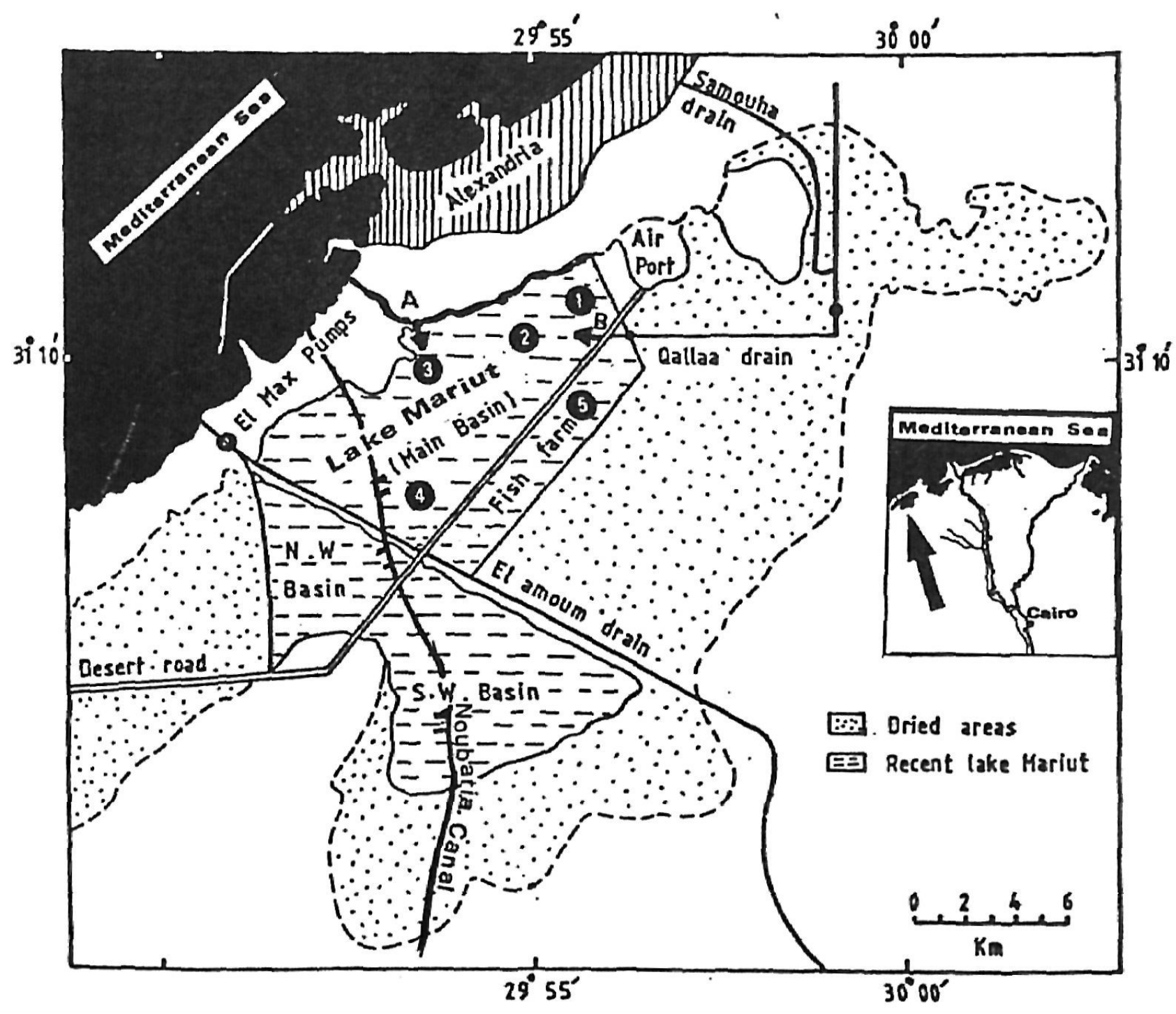

Fig. (1) : Area of study; Lake Mariut, showing the water sampling sites.

A- The western collective treatment station

B- The eastern treatment station 
Table (1). Water quality characteristics of Lake Mariut during 1996/97 (seasonal mean: values)

\begin{tabular}{|c|c|c|c|c|c|}
\hline \multirow{2}{*}{ Parameter } & \multicolumn{5}{|c|}{ Stations } \\
\hline & 1 & 2 & 3 & 4 & 5 \\
\hline $\mathrm{pH}$ & 7.4 & 7.5 & 7.8 & 8.5 & 8.1 \\
\hline $\mathrm{Ec}\left(\mu \mathrm{mhos} \mathrm{cm}^{-1}\right)$ & 6.5 & 4.2 & 2.9 & 1.1 & 1.8 \\
\hline $\mathrm{SO}_{4}\left(\mathrm{mg} \mathrm{l}^{-1}\right)$ & 610 & 550 & 510 & 297 & 230 \\
\hline $\mathrm{H}_{2} \mathrm{~S}\left(\mathrm{mg} \mathrm{l}^{-1}\right)$ & 15 & 30 & 16 & 2.8 & 3.5 \\
\hline $\mathrm{NH}_{3}\left(\mathrm{mg} \mathrm{l}^{-1}\right)$ & 26.9 & 28.1 & 26.3 & 10.8 & 5.9 \\
\hline $\mathrm{NO}_{2}\left(\mathrm{mgN} \mathrm{l}^{-1}\right)$ & 0.020 & 0.030 & 0.025 & 0.39 & 0.6 \\
\hline $\mathrm{BOD}\left(\mathrm{mgO}_{2} \mathrm{l}^{-1}\right)$ & 175 & 182 & 93 & 45 & 15 \\
\hline $\mathrm{COD}\left(\mathrm{mg} \mathrm{O}_{2} 1^{-1}\right)$ & 940 & 985 & 540 & 170 & 85 \\
\hline $\begin{array}{l}\text { Faecal coliform } \\
\text { (MPN } \times 10^{3} 1^{-1} \text { ) }\end{array}$ & 3,800 & 2,500 & 900 & 4.7 & 1.4 \\
\hline
\end{tabular}


Table (2). Water quality characteristics of Lake Mariut during the period $1957 / 58$ and 1996/97 (seasonal mean; values).

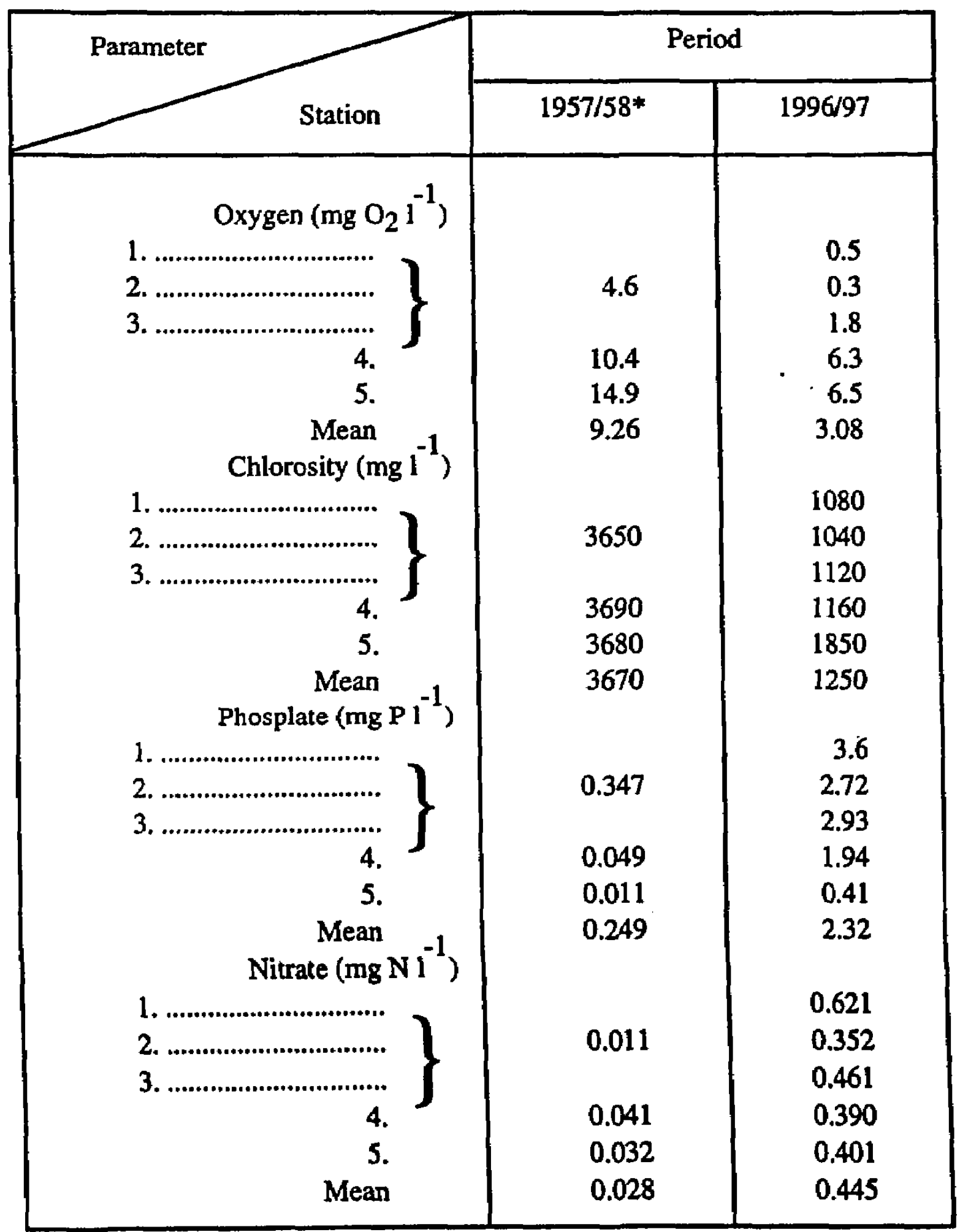

* Wahby, 1961 
Table (3). Heavy metals content $\left(\mathrm{mg} \mathrm{l}^{-1}\right)$ in water of Lake Mariut during $1996 / 97$ ( seasonal means values)

\begin{tabular}{|c|c|c|c|c|c|c|c|}
\hline Stations & $\mathrm{Fe}$ & $\mathrm{Ni}$ & $\mathrm{Zn}$ & $\mathrm{Cu}$ & $\mathrm{Pb}$ & $\mathrm{Cr}$ & $\mathrm{Hg}$ \\
\hline 1 & 9.22 & 0.46 & 0.30 & 0.66 & 0.32 & 0.52 & 0.02 \\
2 & 10.20 & 0.30 & 0.25 & 0.52 & 0.21 & 0.33 & 0.01 \\
3 & 8.21 & 0.22 & 0.22 & 0.49 & 0.22 & 0.21 & 0.02 \\
4 & 4.80 & 0.09 & 0.10 & 0.21 & 0.08 & 0.15 & $\mathrm{ND}$ \\
5 & 3.50 & 0.05 & 0.08 & 0.12 & 0.03 & 0.10 & $\mathrm{ND}$ \\
\hline
\end{tabular}

Table (4). Heavy metals content ( $\mu \mathrm{g} \mathrm{g}^{-1} \mathrm{dry}$ wt) in Oreochromis niloticus of Lake Mariut during 1996/97

\begin{tabular}{|c|c|c|c|c|c|}
\hline & $\mathrm{Fe}$ & $\mathbf{Z n}$ & $\mathrm{Cu}$ & $\mathrm{Pb}$ & $\mathrm{Hg}$ \\
\hline \multicolumn{6}{|l|}{ Fish farm } \\
\hline muscles & 8.5 & 6.5 & 1.95 & 0.43 & ND \\
\hline liver & 15.3 & 27.3 & 8.9 & 2.10 & ND \\
\hline \multicolumn{6}{|l|}{ Main basin } \\
\hline muscles & 35.3 & 19.2 & 9.3 & 0.97 & ND \\
\hline liver & 1230 & 194 & 56 & 15.2 & 0.05 \\
\hline
\end{tabular}


Table (5). Fish production of Lake Mariut during five different periods.

\begin{tabular}{|r|c|c|c|c|c|}
\hline \multirow{2}{*}{ Item } & \multicolumn{5}{|c|}{ Period } \\
\cline { 2 - 6 } & $1921-26 *$ & $1961-65$ & $1975-80$ & $1983-88$ & $1990-96$ \\
\hline $\begin{array}{r}\text { Average annual yield } \\
\text { (tons) }\end{array}$ & 4,339 & 7,400 & 13,800 & 6,800 & 2,800 \\
$\begin{array}{r}\text { Fish production in kg } \\
\text { ha }^{-1}\end{array}$ & 167 & 992 & 1850 & 1120 & 461 \\
$\begin{array}{r}\text { \% catch of } \\
\text { Tilapia spp. }\end{array}$ & 72.6 & 89.7 & 92.3 & 86.9 & 68 \\
$\begin{array}{r}\text { \% catch of other } \\
\text { Nile fishes }\end{array}$ & 12.1 & 7.5 & 2.5 & 11.2 & 30.7 \\
$\begin{array}{r}\text { \% catch of ma- } \\
\text { rine }\end{array}$ & 15.3 & 2.8 & 5.2 & 1.9 & 1.3 \\
\hline
\end{tabular}

* Fouad (1926)

- Other data from Bishai et al (1994) and GAFRD (1997).

Table (6). Annual average values of gross primary production in different areas of Lake Mariut during 1996/97 (seasonal means values).

\begin{tabular}{|c|c|}
\hline Station & $\begin{array}{l}\text { Gross Primary Production } \\
\qquad\left(\mathrm{g} \mathrm{Cm}^{-2} \text { day }^{-1}\right)\end{array}$ \\
\hline 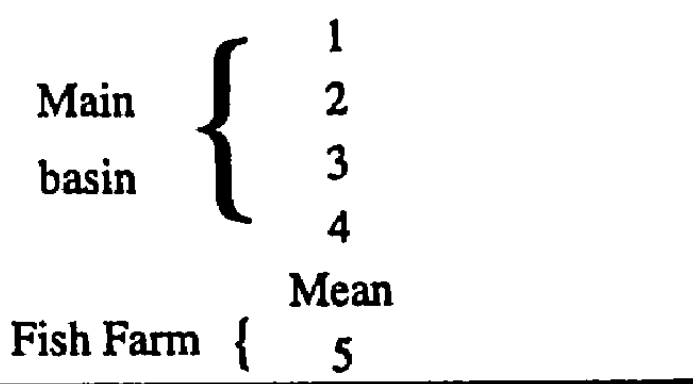 & $\begin{array}{c}0.90 \\
1.32 \\
2.40 \\
2.9 \\
1.88 \\
8.3\end{array}$ \\
\hline $\begin{array}{r}\text { Mean GPP in 1961 } \\
\text { (Aleem \& Samaan, 1969) }\end{array}$ & 6.84 \\
\hline
\end{tabular}


كألمر التلوث على إلتاجية وأنبالك بكيرة مريوط بعمر

\section{مجلدى تواليق خليل

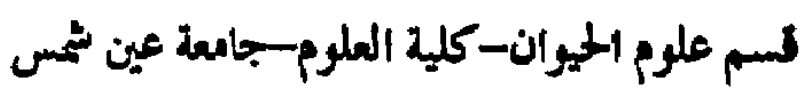

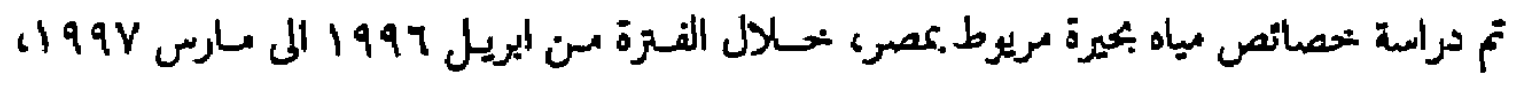

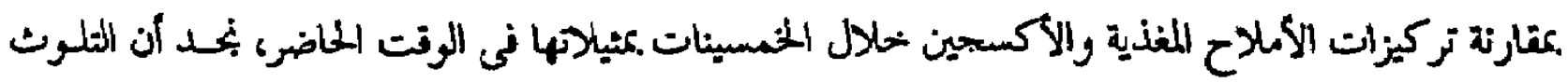

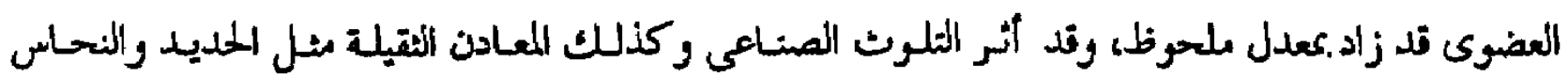

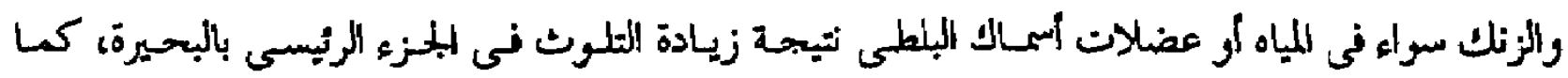

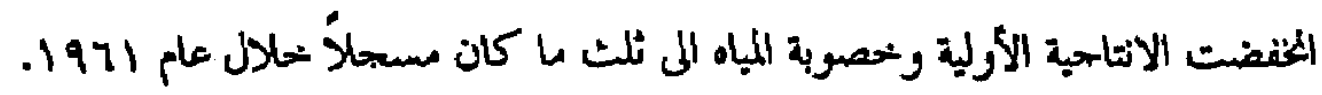

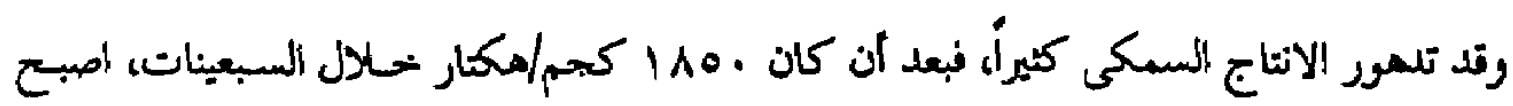

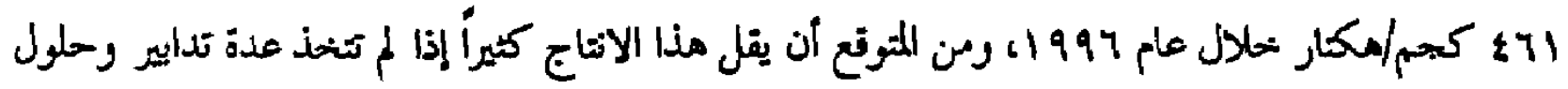
هذريه لتقليل ورتف هذا التلوث فى مذه البحيرة الملامه. 